\title{
An Empirical Study about the Effect Which "Bao Bao" Internet Monetary Funds Make on Deposits in Chinese Commercial Banks
}

\section{Jinjin Gong, Xiaofen Ye, Zhilong Liang}

Economics and Management Department, Zhujiang College of South China Agricultural University, Guangzhou, China

Email: jinjin_2496@126.com

How to cite this paper: Gong, J.J., Ye, X.F. and Liang, Z.L. (2016) An Empirical Study about the Effect Which "Bao Bao" Internet Monetary Funds Make on Deposits in Chinese Commercial Banks. American Journal of Industrial and Business Management, 6, 9931000.

http://dx.doi.org/10.4236/ajibm.2016.69095

Received: August 18, 2016

Accepted: September 25, 2016

Published: September 28, 2016

Copyright $\odot 2016$ by authors and Scientific Research Publishing Inc.

This work is licensed under the Creative Commons Attribution International

License (CC BY 4.0).

http://creativecommons.org/licenses/by/4.0/

\begin{abstract}
This paper chooses 14 listed banks in China June 2013 to March 2016 quarter data as sample, exploding the effect of "Bao bao" Internet monetary funds on deposits in commercial banks based on the econometric model. The empirical results show that "Bao bao" Internet monetary funds have not been diverted the deposits balance of commercial banks, but it increases the cost of deposits of commercial banks, and brings a certain amount of pressure on interest payments of Chinese commercial banks.
\end{abstract}

\section{Keywords}

"Bao Bao" Internet Monetary Funds, Deposits of Chinese Commercial Banks, Empirical Study

\section{Introduction}

In a narrow sense, The Internet Currency Fund is not only a kind of emerging Internet financial management mode, which draws support from platforms developed by the third party. However, it is also called The "Bao bao" Internet Monetary Fund by Chinese scholars due to the name of these Internet Monetary Fund with Bao word. In June 2013, Alipay associated with TIANHONG Fund, resulted in establishing a far-reaching Internet currency fund lately named Yu'E Bao. Since its establishment, Yu'E Bao has engaged in a rapid development. Within only a year, it scaled up to 574.16 billion yuan, as well as reaching 100 million clients. Subsequently, it became the hottest single fund around the world, as its users and accumulated benefit have achieved 295 million and 57.293 billion respectively by the end of June 2016. In January 2014, inspiring by such a profitable mode, some large Internet companies started to imitate Alipay by cooperat- 
ing with domestic fund enterprises, founded a series of "Bao bao" currency funds like Licai Tong, Lingqian Bao, Baidu Bai Zhuan Li etc. Therefore, Internet currency funds entered a short stage of quick progress. The platforms that "Bao bao" Internet Monetary Fund belongs to are shown in Table 1.

As a typical representative of Internet finance, Internet Monetary Fund would easily make a threat to commercial Banks by the advantages of its low threshold and relatively high yield. Thus at the end of 2014, Chinese Central Bank posted to those "Bao bao" currency funds, announcing their money deposited in commercial bank would turn into general accounts, which necessitated them to pay for the reserve requirement. The measure from Central Bank soon directly caused a sharp decrease to the yield rate of "Bao bao" in 2015. For instance, the seven-day annualized yield of Yu'E Bao in the third quarter of 2015 showed a decline of 35.2 percent compared with the second quarter ${ }^{1}$. Nevertheless, the average deposit of 14 listed domestic commercial banks in the third quarter of 2015 surprisingly ascended by $35.71 \%$ compared with the second quarter ${ }^{2}$. Do "Bao bao" Internet currency funds truly bring an obvious impact on saving business of commercial banks? Based on the background above, this paper will mainly take the empirical approach to examine the level of influence that "Bao bao" brings to the banks.

\section{Theoretical Analysis}

A theoretical study has already been taken on by domestic scholars since the events happened. For example, Jing Zhang (2014) asserted that Internet monetary capitals led by Yu'E Bao resulted in distribution of demand deposits in commercial banks [1]. Liancheng Zheng (2014) argued that Internet finance had limited impacts on banking industry, but its long-term implication would be intensified. He also referred that a

Table 1. The platforms that "Bao bao" Internet Monetary Fund belongs to and cooperation funds ${ }^{3}$.

\begin{tabular}{ccc}
\hline Names & Platforms & Cooperation funds \\
\hline Yu'E Bao & Alipay & Tianhong Fund \\
Licai Tong & Tencent Wechat & Huitianfu Fund \\
Baidu Bai Zhuan Li & Baidu & Huaxia Fund \\
Xianjin Bao & Suning Easy pay & Huitianfu Fund \\
Lingqian Bao & Suning cloud service provider & Guangfa Fund \\
Pingan Ying & Pingan Bank & Nanfang Fund \\
\hline
\end{tabular}

\footnotetext{
${ }^{1}$ The data comes from official website of TianHong Fund.

${ }^{2}$ The 14 listed domestic commercial banks refer to Industrial and commercial bank of China, bank of China, agricultural bank of China, China construction bank, bank of communications, China merchants bank, Citic bank, China minsheng bank, Shanghai pudong development bank, industrial bank, ping an bank, China everbright bank, ningbo bank, bank of Beijing, the data comes from quarterly financial statement of the banks above.

${ }^{3}$ In 2015, these six "Bao bao" Internet monetary fund market shares accounted for more than 95\% of all in our country.
} 
certain impact would also take place in the negotiated deposits of banks [2]. From the author's perspective, compared with liabilities of deposits, "Bao bao" Internet Monetary funds provide flexibility of operation, superior experiences for clients and a higher yield rate than banks', hence it gives rise to a certain distribution of personal savings. However, as finally there are parts of funds from "Bao bao" will turn into negotiated deposits, the research for the specific effect which "Bao bao" Internet Monetary Fund make on the balance of Bank savings will need a further analysis.

\section{The Empirical Analysis of the Influence on Saving Business in Commercial Banks}

\subsection{Variable Selection}

\section{1) Setting of the explained variables}

Informed by the analysis above, the impact from "Bao bao" Internet monetary funds mainly reflects in the distribution of saving business. Indexes for measuring deposit are principally composed of balance of savings and average balance of deposits. As the sample data selected by the author is in quarter, which focuses on the influence on average balance of savings in commercial banks of each quarter. Therefore, the author chooses the quarter average deposits of commercial banks as the explained variable.

\section{2) Setting of explanatory variables}

The explanatory variable of this paper is "Bao bao" Internet monetary funds, main indicators for measuring yields of Internet monetary funds are seven-day annualized yield and daily net value of fund units, we think seven-day annualized yield is more suitable for the quarterly analysis than daily net value of fund units for its smoothness, therefore we choose seven-day annualized yield of "Bao bao" Internet monetary funds as measurement indicator. However, the seven-day annualized yield of each Internet monetary fund was inconsistent, this paper chose the geometric mean of seven-day annualized yield of 6 Internet monetary funds including Yu'E Bao, Licai Tong, Lingqian Bao, Baidu Bai Zhuan Li, Xianjin Bao, Pingan Ying as the index for measuring the Internet currency funds.

\section{3) Setting of controlled variables}

Apart from the Internet monetary Fund, there are a lot of factors that affected the commercial banks deposits. Refereeing to the existing papers, this paper argued that factors influencing the balance of commercial banks included deposit interest rate, consumer expectation, stock investment return rate and real estate investment.

a) Deposit interest rate: Bank deposit rate was an important factor affecting the deposits of commercial bank. In General, the deposit interest rate is proportional to the absorption of commercial bank deposits. Bao jinghai and Ma Lihua (2013) believed that fixed-term deposit was the largest proportion of savings deposit, and among them, the percentage of 1-year Term deposit is the largest [3]. Therefore, this paper chose 1-year fixed-term deposit interest rate as a deposit interest rate measurement indicator.

b) Consumer expectation: consumer expectation is a kind of consumption propensity judged by the market and economic conditions. According to the Modigliani life 
cycle theory, Current consumption and saving behavior of residents, determined not only by their current income, but also by their expected future earnings of the decision. Therefore, this paper chooses the consumer expectation index as measurement indicator of consumer expectation, the index can show the future income and economic prospects of consumers, if the index is high, we can believe consumers have strong propensity to the current consumption, savings will be reduced accordingly.

c) Stock investment return rate: Stock return on investment is another important indicator to the deposit balance of commercial banks in China. Due to imperfect capital markets, there is great speculation space of Chinese stock investment, which is particularly obvious in a bull market. When the stock return on investment is high, residents will transfer the assets from banks to the stock market, and result in a diversion of bank deposits. This paper chooses the geometric mean of Shanghai composite index as measurement indicator of stock investment return rate according to the literature of Tan Zhengxun (2006) [4].

d) Real estate price index: In recent years, real estate industry has been hot in China, more and more people choose to buy housing as a means of capital gains, and Savings deposits mainly came from people's idle money. In the case of real estate investment heating up, it will be able to divert savings deposits in banks. The real estate price index is an authority index of measuring real estate popularity [5] [6], however, the real estate price index's data only before 2011 in China, so we chose Hundred-price index counted by Chinese real estate Statistical Yearbook as a proxy. All the Variables are shown in Table 2.

Table 2. Variable list of paper.

\begin{tabular}{|c|c|c|}
\hline Variable types & Name of index & Notes \\
\hline $\begin{array}{l}\text { Explained } \\
\text { variable }\end{array}$ & $\begin{array}{c}\text { Quarter average } \\
\text { deposits of } \\
\text { commercial banks (qdes) }\end{array}$ & $\begin{array}{c}\text { Quarter average deposits of commercial } \\
\text { banks = quarter deposit balance of } \\
\text { commercial banks/quarter days }\end{array}$ \\
\hline $\begin{array}{c}\text { Explanatory } \\
\text { variables }\end{array}$ & $\begin{array}{l}\text { Seven-day annualized yield } \\
\text { of "Bao bao" Internet } \\
\text { monetary funds (efrate) }\end{array}$ & $\begin{array}{l}\text { The geometric mean of seven-day annualized yield } \\
\text { of } 6 \text { Internet monetary funds including Yu'e Bao, } \\
\text { Tencent financial management, Baidu profits, } \\
\text { Cash baby, pocket money baby, Ping an surplus }\end{array}$ \\
\hline \multirow{4}{*}{$\begin{array}{l}\text { Controlled } \\
\text { variables }\end{array}$} & $\begin{array}{l}\text { Deposit interest } \\
\text { rate (rate) }\end{array}$ & 1-year fixed-term deposit interest rate \\
\hline & $\begin{array}{c}\text { Consumer expectation } \\
\text { index (CEI) }\end{array}$ & - \\
\hline & $\begin{array}{l}\text { The Shanghai } \\
\text { composite index (szss) }\end{array}$ & - \\
\hline & $\begin{array}{l}\text { Hundred-price index } \\
\text { of real estate (reits) }\end{array}$ & - \\
\hline
\end{tabular}

${ }^{4}$ In the six Internet monetary Fund, apart from Yu'E Bao launched in June 2013, and 5 other species were introduced in January 2014, therefore the data of 2013 mainly is seven-day annualized yield of Yu'E Bao, and in 2014 and beyond data is 6 Internet Fund's geometric mean of the seven-day annualized yield. 


\subsection{Description of Sample Data}

This paper chooses the quarterly data of 14 listed banks in a period from June 2013 to March 2016 as sample, including Industrial and Commercial Bank of China, Bank of China, Agricultural Bank of China, China Construction Bank, Bank of Communications, China Merchants Bank, China CITIC Bank, China Minsheng Bank, Shanghai Pudong Development Bank, Industrial Bank, Ping An Bank, Bank of Ningbo, Bank of Beijing. The deposit balance data comes from the annual report published quarterly by these banks. The data of seven-day annualized yield of "Bao bao" Internet monetary funds, Index of Consumer Expectations and return rate of Shanghai Composite Index is from Chinese financial Statistical Yearbook [7]. And the data of China Hundredprice index of real estate comes from Chinese real estate Statistical Yearbook.

\subsection{Stationarity Tests}

In order to avoid spurious regression, this paper does stationarity tests on the tested series before empirical analysis. To evaluate the stationary of every series accurately, we resorted to ADF Test. A stationary series is denoted as I(0); For a non-stationary random series, if it becomes into a stationary series after single-difference, it is said to have first-order integration and denoted as I (1) [8]. We computed qdes, efrate, rate, CEI, szss and reits on the sample data and did ADF Test. Chart 3 shows the results.

As Table 3 shows, qdes $\sim \mathrm{I}(1)$, Efrate $\sim \mathrm{I}(1)$, rate $\sim \mathrm{I}(1)$, CEI $\sim \mathrm{I}(0)$, szss $\sim \mathrm{I}(1)$, reits $\sim \mathrm{I}(1)$, which indicates that except for CEI that is stationary, the others all have first-order integration.

\subsection{Empirical Model and Regression Results}

According to the ADF test results, the order of the variables is not consistent. To ensure the validity of the model and prevent large values, we did log processing for all variables, then did differential treatment for the logarithm of all the first-order integrated variables to explore the impact of growth rate of return of the Internet monetary funds on the growth rate of deposit balance of commercial banks.

$$
\begin{aligned}
\mathrm{d}(\text { lnqdes })_{i t}= & \alpha_{0}+\alpha_{1} \mathrm{~d}(\text { lnEfrate })_{i t}+\alpha_{2} \mathrm{~d}(\text { lnrate })_{i t}+\alpha_{3} \text { lncei }_{i t} \\
& +\alpha_{4} \mathrm{~d}(\text { lnszzs })_{i t}+\alpha_{5} \mathrm{~d}(\text { lnreits })_{i t}+\varepsilon_{i t}
\end{aligned}
$$

Table 3. ADF test results.

\begin{tabular}{cccccccc}
\hline Test type $(c, t, j)$ & Test indicators & qdes & Efrate & Rate & cei & szzs & reits \\
\hline & ADF-value & 10.789 & 24.11 & 38.41 & $49.82^{\star * *}$ & 10.11 & 2.53 \\
$(\mathrm{c}, 0,0)$ & P-value & 0.9988 & 0.6757 & 0.0927 & 0.0068 & 0.9992 & 1.0000 \\
$(\mathrm{c}, 0,1)$ & ADF-value & $113.66^{* * *}$ & $68.41^{\star * *}$ & $67.41^{\star * *}$ & $47.42^{\star *}$ & $41.07^{\star * *}$ & $120.69^{\star * *}$ \\
& P-value & 0.0000 & 0.0000 & 0.0000 & 0.0124 & 0.0025 & 0.0000 \\
\hline
\end{tabular}

Note: ${ }^{\star}$ means significant at $10 \%$ level; ${ }^{\star *}$ means significant at $5 \%$ level; ${ }^{\star * *}$ means significant at $1 \%$ level. 
$i=(1,2,3, \cdots, 14), t=(2013.6, \cdots, 2016.3)$, is stochastic error. With EVIEWS6.0 software, we get the following regression results.

From column 4 of Table 4, we know that when the only independent variable is the seven-day annualized rate of return of the Internet monetary funds, the seven-day annualized rate of return of "Bao bao" Internet monetary funds has an significant negative impact on the growth rate of quarterly average deposit of commercial banks, but the correlation coefficient of the model is very small, which indicates that the correlation coefficient of the seven-day annualized rate of return of "Bao bao" Internet monetary funds and the quarterly average deposit balance of commercial banks is very small. And the empirical results of column 2 to column 5 show that the impact of the seven-day annualized rate of return of "Bao bao" Internet monetary funds on the growth rate of quarterly average deposit of commercial banks is not significant, which indicates the emergence of "Bao bao" Internet monetary funds do not divert the deposit of commercial banks. We think the reason is that though there may be some division on the savings deposit, the money of Internet monetary funds will end up in commercial banks as contracted deposit anyway. Therefore the quarterly average deposit balance of commercial banks does not change much, but the conversion to contracted deposit of some savings deposit may cause raise of commercial banks' interest expense. To verify this assumption, we take the growth rate of the interest expense as dependent variable ${ }^{5}$, and explored the impact of the growth rate of Internet monetary funds' return rate on it. The result of column 6 shows that the growth rate of Internet monetary funds' return

Table 4. Regression results of the impact of Internet monetary funds on commercial banks' deposit balance.

\begin{tabular}{|c|c|c|c|c|c|c|}
\hline Test type & $\begin{array}{c}\mathrm{d} \text { (ln qdes) } \\
\quad(1)\end{array}$ & $\begin{array}{c}\mathrm{d} \text { (ln qdes) } \\
(2)\end{array}$ & $\begin{array}{c}\mathrm{d} \text { (ln qdes) } \\
\text { (3) }\end{array}$ & $\begin{array}{c}\mathrm{d} \text { (ln qdes) } \\
(4)\end{array}$ & $\begin{array}{c}\mathrm{d} \text { (ln qdes) } \\
(5)\end{array}$ & $\begin{array}{c}\mathrm{d}(\ln \operatorname{lxzc}) \\
(6)\end{array}$ \\
\hline $\mathrm{C}$ & $\begin{array}{l}-0.03 \\
(-0.92)\end{array}$ & $\begin{array}{l}-0.03 \\
(-1.04)\end{array}$ & $\begin{array}{l}-11.54 \\
(-1.91)\end{array}$ & $\begin{array}{l}-12.66 \\
(-2.01)\end{array}$ & $\begin{array}{l}-14.26 \\
(-2.22)\end{array}$ & \\
\hline $\mathrm{d}$ (ln Efrate) & $\begin{array}{c}-0.59^{* * *} \\
(-3.17)\end{array}$ & $\begin{array}{c}0.01 \\
(0.05)\end{array}$ & $\begin{array}{l}-0.12 \\
(-0.51)\end{array}$ & $\begin{array}{l}-0.06 \\
(-0.26)\end{array}$ & $\begin{array}{l}-0.22 \\
(-0.73)\end{array}$ & $\begin{array}{l}0.87^{\star *} \\
(2.08)\end{array}$ \\
\hline d (lnrate) & & $\begin{array}{c}-0.42^{\star * *} \\
(-3.12)\end{array}$ & $\begin{array}{c}-0.47^{\star * \star} \\
(-2.12)\end{array}$ & $\begin{array}{c}-0.54^{\star * *} \\
(-2.41)\end{array}$ & $\begin{array}{l}-0.23 \\
(-0.51)\end{array}$ & \\
\hline Incei & & & $\begin{array}{l}2.46^{* *} \\
(1.91)\end{array}$ & $\begin{array}{l}2.70^{* *} \\
(2.01)\end{array}$ & $\begin{array}{l}3.05^{* *} \\
(2.22)\end{array}$ & \\
\hline $\mathrm{d}$ (lnszzs) & & & & $\begin{array}{l}-0.20^{\star} \\
(-1.98)\end{array}$ & $\begin{array}{l}-0.13^{\star} \\
(-1.56)\end{array}$ & \\
\hline d (lnreits) & & & & & $\begin{array}{c}2.67 \\
(0.80)\end{array}$ & \\
\hline $\mathrm{R} 2$ & 0.072 & 0.21 & 0.23 & 0.21 & 0.24 & 0.67 \\
\hline $\mathrm{P}$-value & 0.0012 & 0.0123 & 0.0062 & 0.0000 & 0.0091 & 0.0006 \\
\hline DW-value & 2.63 & 2.85 & 2.87 & 2.76 & 2.85 & 2.22 \\
\hline
\end{tabular}

Note: ${ }^{\star}$ means significant at $10 \%$ level; ${ }^{\star *}$ means significant at $5 \%$ level; ${ }^{\star * *}$ means significant at $1 \%$ level.

${ }^{5}$ The interest expense is I (1), so this paper directly establishes regression model after the differential treatment of its logarithmic. 
rate has a significant positive impact on the growth rate of the commercial banks' interest expense. The return rate of Internet monetary fund grew one percent, the commercial banks' interest expense will increase 0.87 percent. Therefore Internet monetary funds do not divert the deposit of commercial banks, but, to a certain degree, aggravated their interest expense burden.

Among other indicators that affect the deposit balance of commercial banks, the growth rate of deposit rate has a significant negative effect on the growth rate of quarterly average balance of commercial banks, which is contrary to theory. We think this may be attributed to the sample data. As we know, the deposit rate of commercial banks in China is up to People's Bank of China. During June 2013 and March 2016, China adjusted interest rate irregularly, which reached up to 6 times. Therefore, the data of deposit rate is not continuous, which makes a bad influence on the empirical results.

In addition, the growth rate of stock returns has a negative effect on the growth rate of quarterly average deposit of commercial banks, which is consistent with our analysis. The fact that Index of Consumer Expectations has a positive effect on the growth rate of quarterly average deposit of commercial banks is contrary to Modigliani's Life Circle Hypothesis of Consumption. We think this may be related to the conservative consumption idea of Chinese people. Although the Index of Consumer Expectations grows, the pressure of medical and education makes Chinese tend to save, therefore quarterly average deposit of commercial banks grows with Index of Consumer Expectation. The impact of the price index of real estate on the growth rate of quarterly average deposit of commercial banks is not very significant. We think this may be related to the index we chose. This article chooses Hundred-price index of real estate price index which is based on the average real estate price of one hundred main cities in China. But the growth rate of quarterly average deposit of commercial banks, which is the dependent variable, is based on the deposit balance of these commercial banks' outlets all over China. The area coverage of the sample data of the argument influences empirical results.

\section{Conclusions}

Through empirical research, this paper draws the following conclusions:

1) "Bao bao" Internet monetary funds have not been diverted the deposits balance of commercial banks, but it increases the cost of deposits of commercial banks, and brings a certain amount of pressure on interest payments of Chinese commercial banks.

2) The growth rate of deposit rate has a significant negative effect on the growth rate of quarterly average balance of commercial banks.

3) The growth rate of stock returns has a negative effect on the growth rate of quarterly average deposit of commercial bank.

4) Index of Consumer Expectations has a positive effect on the growth rate of quarterly average deposit of commercial banks.

5) The impact of the price index of real estate on the growth rate of quarterly average deposit of commercial banks is not very significant. 


\section{Funding}

Project: Guangdong provincial reform Fund project "synergy between school and enterprise of independent college under a marketing major construction of applicationoriented talents cultivation bases" (2014974761), the project funded by the special construction project of Guangdong Province discipline and profession, and Zhujiang college of South China Agricultural University.

\section{References}

[1] Zhang, J. (2014) Internet Banking New Industry Model, Potential Risk and Countermeasures. Economic Issues to Explore, 4, 81-85.

[2] Zheng, L.C. (2014) Internet Finance in China: Models, Impact, Nature and the Risks. International Economic Review, 5, 103-118.

[3] Bao, J.H. and Ma, L.H. (2013) Commercial Bank Operation and Management. Department of Higher Education Publishing, Beijing, 7-8.

[4] Tan, Z.X. (2006) Analysis of the Factors Affecting Resident Savings. Commercial Times, 6, 70-71.

[5] Wang, C.Z. (2013) Economic Consideration of Yu’E Bao. Economic Research Guide, 11, 200-201.

[6] Qiu, X. (2013) Yu'E Bao on the Influence and Inspiration of Commercial Bank. The New Financial, 9, 50-54.

[7] Bai, Q. and Tan, Q.H. (2006) The Evolution and Development of Financial Function. Financial Research, 7, 41-52.

[8] Wang, J. (2015) Internet Financial Shape Based on the Financial Function and Its Impact on Commercial Bank. Financial Research, 3, 56-65.

Submit or recommend next manuscript to SCIRP and we will provide best service for you:

Accepting pre-submission inquiries through Email, Facebook, LinkedIn, Twitter, etc.

A wide selection of journals (inclusive of 9 subjects, more than 200 journals)

Providing 24-hour high-quality service

User-friendly online submission system

Fair and swift peer-review system

Efficient typesetting and proofreading procedure

Display of the result of downloads and visits, as well as the number of cited articles

Maximum dissemination of your research work

Submit your manuscript at: http://papersubmission.scirp.org/

Or contact ajibm@scirp.org 